\title{
Extrato do relatorio do Secretário da Faculdade de Direito, referente ao ano de 1949.
}

\section{DIRETORIA}

Estiveram no exercício da Diretoria, durante 1949:

Professor Gabriel José Rodrigues de Rezende Filho - de $1 .^{\circ}$ a 24 de Janeiro de 1949. Nesta data, entrou em gôzo de férias regulamentares, reassumindo a 15 de Fevereiro até 18 de Março, quanda solicitou demissão do cargo de Diretor da Faculdade.

Professor Alvino Ferreira Lima - de 24 de Janeiro a 15 de Fevereiro, durante as férias regulamentares do Diretor, e de 18 de Março a 23 de Junho, datas, respectivamente, em que o Sr. Diretor solicitou demissão, e em que foi nomeado o novo Diretor.

Professor Braz de Sousa Arruda - nomeado Diretor da Faculdade em 21 de Junho, tendo o decreto sido publicado a 23 do mesmo m.ês. Em 7 de Julho, foi publicado Ato do Magnífico Reitor da Universidade, concedendo ao Prof. Braz de Sousa Arruda sessenta dias Ide afastamento, a partir de 17 de Julho, a fim de percorrer diversjos países da Europa, em viagem de intercâmbio universitário. $O$ referido ato foi publicado a 9 de Julho.

Professor Alvino Ferreira Lima - designado, por ato de $12 \mathrm{de}$ Julho, do Magnifico Reitor, para substituir o Prof. Braz de Sousa Arruda, durante o seu afastamento, a partir de 17 de Julho.

Professor Braz de Sousa Arruda - de volta da Europa, reassume o exercicio da Diretoria da Faculdade em 14 de Setembra.

\section{VICE-DIRETORIA}

Professor Alvino Ferreira Lima - de $1 .^{\circ}$ de Janeiro a 27 de Outubro. 
Professor Lino de Moraes Leme - nomeado por decreto de 27 de Outubro. publicado a 28.

\section{CONSELHO TECNICO ADMINISTRATIVO}

Esteve assim constituído: Professôres: Antônio de Sampaio Doria, Alvino Ferreira Lima, Braz de Sousa Arruda, Noé Azevedo, J. J. Cardozo de Mello Neto e Basileu Garcia.

Por ato de 9 de Maic, do Magnífico Reitor, foi nomeado o Professor Waldemar Martins Ferreira para substituir o Prof. J. J. Cardozo de Mello Neto, em virtude da renúncia dêste professor, que assumiu o mandato de Deputado Federal.

\section{PRINCIPAIS DELIBERAÇõES DA CONGREGAÇÃO}

A Congregação dos Professôres da Faculdade de Direito de São Paulo realizou durante o ano de 1949 vinte sessões. Entre suas principais deliberações, contam-se as seguintes:

$$
\text { 1.a sessão - em } 13 \text { de Janeiro de } 1949 .
$$

Nesta sessão, pediu a palavra o Prof. Ernesto Leme, para propor se consignasse em ata voto de satisfação pela presença dos professôres Cardozo de Mello Neto e Jorge Americano, restabelecidos de grave enfermidade. A proposta foi aprovada unânimemente. Os professôres Cardozo de Mello Neto e Jorge Americano agradeceram.

Em seguida, foram aprovadas por unanimidade as seguintes propostas: 1) da Prof. Ernesto Leme, a fim de que a Congregação adira às homenagens que serão prestadas ao Prof. Mendes Pimentel, por ocasião da passagem do seu $800^{\circ}$ aniversário; 2) do Prof. Ernesto Leme, a fim de se consignar em ata um voto de pesar pelo falecimento do Prof. Bernardino José de Souza, da Faculdade de Direito da Bahia; 3) do Prof. Noé Azevedo, no mesmo sentıdo, pelo falecimento do Dr. Otavio Kelly; 4) do Prof. Vicente Ráo, para ficar constando da ata um veemente protesto contra o at antado cometido na Hungria contra o eminente prelado cardeal Joseph Minszenty, comunicando-se o inteiro teor desta proposta a S. Excia. o Sr. Dr. Raul Fernandes, DD. Ministro das Relações Exterior es e às autọridades eclesiásticas do Estado; 5) do Prof. Vicente Ráo, 
no sentido de ser o Dr. Guilherme de Almeida requisitado para ficar adido à Diretoria da Faculdade, a fim de dedicar-se ao estudo de nossos arquivos, publicando-se os seus trabalhos na Revista da Faculdade.

Em seguida, foi lido o ofício do Sr. Tesoureiro da Faculdade. comunicando a entrega que fizera ao "O Estado de São Paulo", da quantia de $\operatorname{Cr} \$ 5.200,00$, dectinada pelos senhores professôres às vitimas das inundações em Minas Gerais.

Logo depois, foram didos os seguintes oficios: 1) do Jrof. Noé Azevedo, presidente da Ordem dos Advogados do Brasil, secção de São Paulo, relativio à homenagem a ser prestada à memória do eminente jurisconsulto João Mendes de Almeida Junior; 2) do livre docente Octavio Guimarães, comunicando que, eın sua última sessão, realizada no dia 30 de Dezembro de 1948, o Instituto da Ordem dos Advogados Brasileiros aprovou o seguinte: "O Dr. Osvaldo Murgel de Rezende commicou ainda desejar instituir um prêmio "Astolfo Rezende" para o melhor aluno que terminasse o curso jurídico ma Faculdade de Direita de São Paulo, consistindo em Cr\$ 2.000,00, em, dinheiro, e uma coleção da Revista de Jurisprudência Brasileira, sugerindo fôsıse o Dr. Octavio Guimarães o portador dessa sugestão à Congregação daquela Faculdade para que deliberasse a respeito" 3) do Centro Acadêmico XI de Agosto comunicando que, em Assembléia realizada no dia 7 do corrente, foi aprovada a consignação em ata de votos de louvor ao Diretor, Dr. Gabriel de Rezende Filho, ao Prof. Vicente Ráo e ao Sr. Flavio Mendes, os quais, em cartas enviadas ao "O Esitado de São Paulo" defenderam o bom nome da Faculdarde.

\section{2. sessão - em 3 de Fevereiro de 1949}

Foi feita verificação de presença dos professôres, tendo constado que se achavam prontos para o serviço os seguintes professôres: Drs. Cardozo de Mello Neto, Braz de Sousa Arruda, Sampaio Doria, Vicente Ráo, Waldemar Ferreira, Mário Masagão, Jorge Americano, Ernesto Leme, Lino Leme, Noé Azevedo, Soares de Faria, Soares de Mella, Cesarino Junior, Alvino Ferreira Lima, J. Canuto Mendes de Almeida, Basileu Garcia, Siqueira Ferreira, Miguel Reale, Th. Monteiro de Barros Filho, Almeida Junior e livres docentes Drs. Pinto Pereira, Genésio de A. Moura, e Luiz Eulálio de Bueno Vidigal. Os professôres Gabriel de Rezende Filho e Alexandre Correia, ausentes desta Capital enviaram comunicação nesse sentido.

A Congregação manteve a designação dos profesisôres Ernesto Leme para substituir o Prof. Cardozo de Mello Neto, ora na Câ- 
mara Federal dos Deputados; do Prof. Miguel Reale, para substituir o Prof. Spencer Vampré, em gôzo de licença para tratamento de saúde; do livre docente Genésio de Almeida Moura, para substituir o Prof. Ataliba Nogueira, também no exercicio do mandato de Deputado Federal. O livre docente Pinto Pereira continua contratado para reger a cadeira de Direito Constitucional. Resolveu ainda a Congregação que o Professor Soares de Faria continue na regência da cadeira de Direito Comercial, em substituição ao Professor Honorio Monteiro.

A Congregação determinou também, que se remetesse ao Conselho Técnico uma proposta do Prof. Cesanino Junior sôbre trabalhos práticos e de seminário de alunos e auxiliares de ensino.

Em seguida, foi reeleita a comissão de redação da Revista da Faculdade de Direito, constituída pelos professôres Soares de Melo, Th. Monteiro de Barros Filho e Almeiäa Junior,

\section{$3 .{ }^{a}$ sessão - em 24 de Fevereiro de 1949}

Do expediente desta sessão, constaram os oficios do Prof. Mendes Pimentel, agradecendo as congratulações que lhe foram enviadas pela passagem do seu $800^{\circ}$ aniversário e do secretário geral do Ministério das Relações Exteriores acusando e agradecendo o ofício relativo ao Cardeal Joseph Mindszenty.

Pediu a palavra o prof. Miguel Reale, que disse: "Considerando que no sistema atual de promoção por média 7 (sete) nas provas escritas torna muito difícil a obtenção de noța igual ou superior a 9 (nove) em tôdas as disciplinas de $5^{\circ}$ ano de Bacharelado, para poder ser conferido o prêmio "João Arruda", proponho que se dê a seguinte redação do art. 5\%. do mesmo Regulamento: "Art. 5. : - O prêmio "João Arruda será conferido ¿o bacharelando jue, alèm de obter nota igual ou superior a 7 (sete) em tôdas as disciplinas do ano, apresentar os dois melhores trabalhos sôbre Filosofia do Direito, sendo um de livre escolha do candidato e cutro incilicado a todos os concorrentes pelo catedrático. Sala da Congregação". Aberta a discussão, falam diversos professôres. Encerraclos os debates, foi a proposta do Prof. Reale submeticla a votos e aprovada contra o voto do Prof. Mário Massagão. O prof. Braz Arruda não votou.

Pelo Prof. Th. Monteiro de Barros Filho foi dito que rem tomando parte, há vários anos, nas bancas dos exames restibulares e notando a declínio progressivo dêsses exames, em virtude de deficiéncia alarmante dos estudos dos cursos secundários. 0 fato anda glingindo às raias do analiabetismo. Como o assunto não consta da ordem do dia, rubmetia-o por hoje, apenas à consideração dos 
colegas, para jue, oporlunamente, a Faculdade dc Direito tomasse a iniciativa de representar aos poderes conpetentes pedinido providências. Competia à Faculdade dar o brado de alarme e era isto que queria submeter à meditação dos senhores professôres. O Professôr Waldemar Ferreira entende que a Faculdade deve, efetivamente, lançar um apêlo público a respeito do assunto. Alssim também entenderam diversos outros professôres, resolvendo, a final, a Ciongregação, eleger uma comissão constituida dos professôres Sampaio Doria, Monteiro de Barros Filho e Almeida Junior, para redigir o apêlo e submetê-lo, em outra sessão, à Congregação.

Passando-se à ordem do dia, pelo Sr. Presidente foi dito que, - Conselho Técnico-Administrativio desta Faculdade, reunido mo dia 22--2-49, tomara conhecimento da lei 619 , de $10-2-49$, publicada a 17, e resolvera admitir à inscrição para os exames de segunda época todos os alunos que a requeressem, considerando que motivos pnderáveis foram aduzidos, oportunamente, pelos estudantes e que a verificação dos referidos motivos ponderáveis, de maneira individual, se revestiria de dificuldades insuperáveis.

\section{4. ${ }^{a}$ sessẫo - em 17 de Março de 1949}

Foi aprovada a seguinte proposta subscrita pelos professôres Waldemar Ferreira, Mário Masagão e J. Soares de Mello: "Tomando conhecimento das resoluções do Conselho Univensitário, em sua se śsão última, de manifesto menosprezo dos títulos de professor catedrático da Faculdade de Direito, e de seu professor livre docente, considerando-os de nenbuma valia no julgamento do concurso de titulos para provimento, por contrato, de cadeiras na Faculdade de Ciências Econômicas e Administrativas; a Congregação dos Profescôres da Faculdade de Direito protesta contra a atitude insólita e de hostilidade do Conselho Universitário e resolve: a) manifestar a sua inteira solidariedade ao Prof. Siqueira Ferreira e ao livre docente Paulo Barbosa de Campos Filho; b) retirar o seu representante na Conselho Universitário. aa) Waldemar Ferreira, Mário Masagão e J. Soares de Mello“.

Depois de encerrados og debates, foi essa proposta aprovada unânimemente, deixando do votar o Prof. Siqueira Ferreira. Pelo Prof. Gabriel de Rezende Filho foi dito que, solidário com seus colegas, dos quais era o representante, presidiria a presente sessão até seu término, e, em seguida, encaminharia ao Magnifico Reitor o seu pedido de demissão do cargo de Diretor. O Prof. Mário Masagão declara que esta atitude do Prof. Gabriel de Rezende Filho muito honra a S. Excia. 
O Prof. Th. Monteiro de Barros Filho pede que conste da at a renúncia que apresenta do cargo de suplente do representante da Congregação da Faculdade de Direito junto ao Conselho Universitário. O Prof. Ernesto Leme, representante da Congregação junto ao Conselho Universitário já apresentara, nessa sessão, a sua renúncia.

Passando-se à ordem do dia, tratou-se em primeiro lugar, do assunto relativo às cátedras đe Direito Constitucional e Teoria Geral do Estado. O Prof. Ataliba Nogueira requereu transferência para a cadeira de Direito Constitucional, tendo o Conselho Técnico-Adminitrativo, em serisão de 18 de Fevereiro dêste ano, tomado conhecimento e indicado os nomes dos Drs. Florivaldo Linhares, Teodomiro Dias e Jorge da Veiga para comporem a comissão que deverá dar parecer sôbre a transferência, na forma da lei. o Prof. Waldemar Ferreira propõe que os professôres que a Congregação designar estudem a possibilidade da supressão da cadeira de Teoria Geral do Estado. A Congregação aceita esta proposta e, em seguida aproviando a proposta do Prof. Ernesto Leme, elege os Profs. Braz Arruda e Walmear Ferreira para completarem a referida comissão.

Foi, em seguida, lido o oficio do Prof. Cardoso de Meln Neto renunciando às funções no Conselho Técnico-Administrativo, por ter asısumido, em caráter definitivo, o cargo de deputado federal.

A Congregação passiou a eleger, em. escrutínio secreto, os nomes dos professôres que deveriam ser enviados ao Magnífico Reitor para escolha do substituto do Prof. Cardozo de Mello Neto. Os nomes mais votados foram os dos Profs. Waldemar Ferreira, com 16 votos e Lino Leme, com 12 votos, nomes êsses que foram enviados ao Magnifico Reitor.

\section{$5^{a}$ sessão - em 24 de Março de 1949}

Nesta sessião, Gs professôres tomaram conhecimento de um mandado de segurança impetrado perante o Juiz de Direito dos Feitos da Fazenda do Estado, por alguns estudantes, contra a Congregação, a fim de que esta cumpra a deliberação do Conselho Universitário, que abonou as faitas dos estudantes em 1948. Dois dos que impetraram o mandado rficiaram ao Sr. Secretário, declarando que haviam dado procuração para que se requeresse um mandado de segurança contra o. Sr. Ministro da Educação e não contra a Congregação da Faculdade de Direito; e que, tendo sido feito tudo à revelia dos referidos estudantes, inclusive a petiçãc. se constideram desligados die sua solidariedade à iniciativa em apreço e que, pelos meios jurídicos, iriam pedir fôssem os seus 
nomes cancelados da procuração, desvirtuada que foi esta em seus fins. Aberta a discussão, nesta intervêm vários professôres. A final foi aprovada uma proposta do Prof. Mário Masagão, a fim de que a Congregação seja representada e defendida por uma comissão cons. tituida pelos Prafis. Alvino F. Lima, Jorge Americano e Ernesto Leme.

\section{2 sessão - 7 de Abril de 1949}

Foi aprovado o Regimento dos Auxiliares de Ensino da Faculdade de Direito, que ficou assim redigido: Art. $10^{\circ}$ - Poderá haver um auxiliar de ensino para cada uma das cadeiras do curso de bacharelado. Art. $20^{\circ}$ - Cada auxiliar de ensino será contratado mediante indicação do professor catedrático, e, por proposta dêste, será a qualquer tempo dispensado. Art. 3.0 - Sòmente poderão ser indicados para auxilares de ensino os bachareis em direito. § 10 - Esta função poderá ser exercida, embora não obrigatòriamente, pelos livres docentes da cadeira; $\S 2 .^{\circ}$ - Para auxiliar da cadeira de Medicina Legal poderá ser indicado quem seja em medicina. Arút. 4. $0^{\circ}$ Compete ao auxiliar de ensino, sob a orientação do professor: a) presidir os trabalhos práticos e de seminário; b) corrigir êsses trabalhos e as dissertações escritas dos alunos, exceto as constitutivas dos exames; c) fornecer aos alunos indicações bibliográficas, e ministra-lihes explicações sôbre as questões propostas pelo professor, que devam constituir objeto de trabalhos escolares; d) auxiliar a fiscalizar a execuçăo de quaisquer provas escritas; e) auxiliar a fiscalização da frequência dos alunós,; f) cumprir, em geral, as determinações do professor, relativas aos trabalhos letivos e sua boa execução. Art. $5 .^{\circ}$ - Os vencimentos dos auxiliares de ensino serão de $\mathrm{Cr} \$ 3.500,00$ (três mil e quinhentos cruzeiros) mensais.

Outro assunto, objeto de debates nesisa sessão, foi o de resolver-se se a solenidade de colação de grau dos bacharelandos de 1948 seria realizada na Faculdade, ou no Teatro Municipal. Por doze votos contra sete, dicidiu-se pela colação de grau no Salão Nobre da Faculdade.

\section{7.a sessão - em 28 de Abril de 1949}

Foi discutida a questão das substituições de professôres catedráticos, intervindo nos debates diversos professôres.

o Prof. Miguel Reale propõe que o C.T.A. proceda à revisão das nomeaçōes dos livres docentes que hajam completado os dez anos e não tenham requerido recondução. O livre docente Genésio 
Moura lembra que deverá ser, também, estudada a situação dos livres docentes nomeados em virtude de aprovação em concurso para catedrático.

Em seguida, a Congregaçã̀o fuicou ciente dos of icios 160, sôbre o Congresso Pró-Paz e 229, referente a questões do ensino, ambos da Reitoria da Universidade.

o Prof. Noé Azevedo relata, em seguida, a visita que o Conselho Técnico recebera do Prof. Zeferino Vaz, encarregado, pela Universidade, de entender-se com os Conselhos Técnicos dos Institutos, sôbre os cursos universitários noturnos, de qụe trạta a Constituição Estadual no n.o 23 das Disposições Transitórias. O Conșelho realizará nova sessão no próximo dia dois de Maio, às 15 horas, e receberá, com esipecial agrado, as sugestões dos senhores professôres a respeito do assunto.

O Prof. Theotônio Monteiro de Barros Filho relata recente visita que fez à Faculdade de Dire to đe Belo Horizonte, assinalando a extrema gentileza do Diretor e professôres daquela Escola para com a Faculdade de Direito de São Paulo, os quais o encarregaram de interpretar, perante esta, a sua estima e admiração. Disse mais que, a convite do Prof. Alberto Deodato, dera aos alunos daquela Faculdade uma aula de Ciência das Finanças.

$$
\text { 8,a sessão - em } 5 \text { de Maio de } 1949^{\circ}
$$

Passando-se à ordem do dia, a Congregação tomou conhecimento do oficio n.a 185, de 27--4-49, do Magnífico Reitor, enviando cópia do parecer relativo ao protesto feito pela Congregação, com referência à atitude do Conselho Universitário no júlgamento do concurso de títulos para provimento de cátedras na Faculdade de Ciências Econômicas. Aberta a discussão, fảlam diversos professôres. O Prof. Mário Masagão propõe, sendo a propostá unânimémente aprovada, que a Congregação mande arquivar o referido ofício.

O Sr. Diretor relatou, em seguida, a visita do Prof. Zeferino Vaz, a respeito da criação dos cursos noturnos. Dabatido o assunto, a Congregação resolveu, aprovando proposta do Prof. Cesarino Jr., que o Conselho Técnico elabore um projeto de criação dos cursos noturnos, o qual será, oportunamente, apreciado pela Congregação.

$$
\text { 9. }{ }^{a} \text { sessão - em } 15 \text { de Junho de } 1949
$$

Aberta a sessão, passando-se à ordem do dia, pelo Sr. Diretor foi dito que, tendo sido dispensado, a pedido, o Prof. Gabriel Rezende Filho, por decreto de 10 do corrente, da função de Diretor desta Faculdade, convocara a presente sessão para que a Congrega- 
ção indicasse dois professôres, na forma da lei, para a referida função. Feita a eleição, em escrutinio secreto, verificou-se que os professôres Braz de Souza Arruda e Lino de Moraes Leme foram os mais votados, aquêle, com 11 votos e êste, com 5. O Sr. Presindente declarou que levaria à Reitoria e ao Govêrno os nomes dos referidos professôres, para, dentre êles, ser nomeado o novo Diretor da Faculdade de Dúreito. Os professôres Braz de Sousa Arruda e Lino de Moraes Leme agradeceram aos seus colegas a indicação dos seus nomes.

Pediu a palavra o Prof. Ernesto Leme para propor fôsse consignado em ata um voto de congratulações ao prof. Almeida Junior pela sua recente indicação para o Conselho Nacional de Educação. A proposta foi aprovada unânimemente.

Pediu a palavra o Prof. Soares de Mello, para propor fôsce consignado em ata um voto de pesar pelo falecimento do Dr. Oscar Drummond Costa, eminente advogado, hoje falecido, oficiando-se a família, nêsse sentido. A propasta foi aprovada unânimemente.

Pediu a palavra o Prof. Basileu Garcia para propor que fôsse presente à Congregação a Provisão do Conselho Técnico relativa ao livre docente Pinto Pereira, embora não conste esta da ordem do dia. Discutida a proposta Basileu Garcia, foi ela aprovada, e, então, procedida pelo Sr. Secretário, a leitura da seguinte Provisão: "O Conselho entendeu que o decreto do Govêrno, que assegurou ao Prof. M.F. Pinto Pereira a situação de estável como servidor público, the criou, ao mesmo tempo, uma situação singular. Não chegou a catedrático, mas foi além de livre docente. E caso não previsto nas leis de ensino. Para definir a situação de servidor público estável, pois que a iniciativa de a propor ao Govêrno partiu da Congregação, parece ao Conselho que se poderia reconhecer no Prof. Pinto Pereira direito a tomar parte nos trabalhos da Congregação, menos o de votar em matéria de concursos e para o provimento de catedrático. Nesta matéria só podem ter voto professôres catedráticos. Excluída esta função, nada obsta a que o Prof. Pinto Pereira participe, do mais, como se catedrático fôsse. É o que parece razoável, em consequência da apostila feita no seu título por ordem do Governador do Estado, que declarou que o Prof. Pinto Pereira é servidor público estável, com remuneração correspondente à do cargo de professor catedrático, padrão "S", do quadro da Universidade de São Paulo". Terminada a leitura, foi a provisão do Conselho Técnico unânimemente aprovada.

0 Prof. Soares de Mello propõe que conste da ata um voto de congratulação e homenagem ao Prof. Gabriel de Rezende Filho, diretor demissionário, lembrando que o mesmo remonta à primeira 
geração de professôres desta Ciasa, e que, nesta ata se consigne a expressão do profundo reconhecimento e gratidão, ao Prof. Gabriel de Rezende Filho, pela sua atuação na Diretoria da Faculdade. A proposta foi aprovada por todos.

Pediu a palavra o Prof. Soares de Mello e por êle foi dito que: "a galeria de retratos da Faculdade é uma das mais valiosas do Brasil, sendo mesmo poucas as escolas superiores no mundo, que a possuem maior. São setenta retratos a óleo. Alguns bem antigos, como os de Gabriel Rodrigues dos Santos e Avelar Brotero. Muitos são de grande vvalor artístico, como os de Falcão Filho e Rubino de Oliveira, da autoria de Almeida Junior. Alguns, de pintures ignorados, como os de Alvares de Azevedo, José Bonifácio, Justinc, de Andrade, Conselheiro Ribas. Pois bem. E indispensável que se cuide sèriamente dêsse valiosíssimo patrimônio astístico. Os quadros, com exceção, talvez de dois ou três, estão necessitando de limpcza e remoçãa de vernizes velhos. Para alguns será imprescindivel maiores reparos: retoques na moldura, imunização contra cumpim e traças. Assim sendo, chamando a at'enção dos meus doutos colegas, para o assunto, proponho que a Congregação autorize o Sr. Diretor a contratar um técnico para êsise serviço. E ainda: mande fazer o retrato a óleo, para aumentar a nosisa galeria, e como expressiva homenagem desta Escola, a Professor Emérito Reinaldo Porchat, cujo meio sécullo de profícuas atividades em pról do ensino superior no Brasil foi aqui solenemente comemorado". As propositas do Prof. Soares de Mello foram aprovadas unânimemente.

\section{$10 .{ }^{a}$ sessão - em 30 de Junho, de 1949}

Aberta a sessâo, pelo Sr. Presidente foi dito que convocara a presente sessão a fim de receber o Prof. Braz de Sousa Arruda, nomeado diretor da Faculdade de Direito por decreto de 21 do corrente, e empossado pelo M. Reitor em 23, pelo que convidava os professôres Cesarino Jr. e Monteiro de Barros Filho para acompanharem o Prof. Braz Arruda, que se achava na sala da diretoria até o Salão Nobre, o que foi feito com as formalidades de estilo. Em seguida, o Prof. Vicente Ráo, em nome da Congregação, saudou o novo Diretor. Logo após, a bacharelando José Luiz de Anhaia Mello, Presidente do Centro Acadêmico XI de Agosito, saudou o Prof. Braz Arruda, em nome dos estudantes. Por fim, usou da palavra o Prof. Braz Arruda, que respondeu agradecendo. 


\section{$-181$ \\ 11.a sessão - em 9 de Julho de 1949}

As 10 horas do 9 de Julho de 1949, no salão, nobre desta Faculdade, realizou-se sessão cívica, em comemoração à data, com a presença doıs professôres catedráticos Drs. Braz de Souza Arruda, diretor, Erneste Leme, Soares de Faria, Miguel Reale e livres docentes Sinésio Rocha, Gama e Silva e Francisco Oscar Penteado Stevenson. Entre os convidados achavam-se presentes: Dr. Alfredo Ellis, Dr. Plinio Games Barbosa, juiz de direito, Dr. Otavio Barros, secretário do Ministério Público, Dra. Carlota Pereira de Queiroz, Dr. Guilherme de Almeida, Dr. Lucio Cintra do Prado, presidente da Associação dos Antigos Alunos, e Camilo Antonio Mourão, da Academia de Letras da Faculdade. A mesa que dirigiu a solenidade foi presidida pelo Pruf. Dr. Braz Arruda e assim constituida: Cel. Raimundo Sampaio, defensor do Túnel em 32; Dr. Lucio Cintra do Prado, representante do Secretário da Segurança; Odir Porto, presidente interino do Centro Acadêmico XI de Agosto e Joaquim Penteado, representante do Reitor da Universidade. Após referir-se à importância que representava para São Paulo e principalmente para a Faculdade de Direito a data de 9 de Julho, o presidente da mesa deu a palavra ao poeta Dr. Guilherme da Almeida, ex-combatente, que procedeu à leitura do manifesto da Congregação da Faculdade em 15 de Julho de 1932, associando-se com a Revolução redentora que veio trazer dias de liberdade para São Paulo e para o Brasil.

\section{MANIFESTO DA CONGREGAÇÃO}

"O Estado de São Paulo de 16 de Julho de 1932 — Os professôres da Faculdade de Direito solidários com o movimento.

A "Rádio Sociedade Record" irradiou ôntem, às 19 horas e 45 minutos, o seguinte manifesto:

E' o seguinte o Manifesto da Congregação, irradiado a $15 \mathrm{de}$ Julho de 1932: “A Congregação dos Professôres da Faculdade de Direito de São Paulo vem afirmar pùblicamente e sua absoluta solidariedade com o movimento irresistível, em que está empenhado o povo paulista, em comunhão com as fôrças armadas para a restauração imediata da ordem legal no Brasil. Seríamos indignos da missão que nos incumbe, na formação da consciência jurídica da nacionalidade, se não estivessemos, como estamos, de corpo e alma, ao lado de nossos bravos alunos, todos incorporados às fileiras, nesta campanha nobilissima contra a ditadura, que representa e encarna 
a negação do direito. A nevolução é um meio e năo uma finalidade; um remédio e não um regime político; uma arma e' não um ídolo. Triunfante a de 1930, cumpria-lhe conventer desde logo em realidade as ideais que the asseguraram o triunfo. Perpetuar cavilosamente um govêrno que é de nome e deve ser de fato, um govêrno provisório, negar ao povo o direito de estabelecer, por delegados de sua confiança, a organização política do país, conservar sob uma curatela humilhante 40 milhões de brasileiros, até que se convertam a uma ideologia, cujos arautos têm o cuidado de a conservar inédita, é afronta que homens livres não toleram, e que nós, professôres de direito, mais da que ninguem, temos o dever de repelir e condenar. A liberdade dentro da lei, a obediência dentro da dignidade, a independência dentro da disciplina - eis, em suma, o que ensinamos às novas gerações, eis o que o Exército Nacional, a polícia militar e tôdas as fôrças vivas de nossa terra estão reivindicando para o Brasil. Coerentes com os ensinamentos que pregamos, fieis às tradições de civismo da escola, em que ensinou Pedro Lessa e aprendeu Rui Barbosa, herdeiros dos homens que fizeram a Independência, a Abolição e a República, outra não pode ser nossa atitude, se não ombro a ombro com os soldados da lei, que se batem pela união indissolúvel dos brasileiros, à sombra de uma constituição liberal. São Paulo, 15 de Julho de 1932. - Dario Ribeiro, Alcantara Machado, Pinto Ferraz, Manuel Villaboim, Candido Mota, Reynaldo Porchat, João Arruda, Gama Cerqueira, Rafael Sampaio, Azevedo Marques, Parheco Prates, Cardoso de Mello Neto, Francisco Morato, Braz Arruda, Sampaio Doria, Waldemar Ferreira, Laurentino Azevedo, Gabriel de Rezende Filho, Hermes Lima, A. F Almeida Junior, Mário Masagão, Noé Azevedo, Honorio Monteiro, Jorge Americano, Pinto Pereira e A. C. Pacheco e Silva."

Em seguida, o Prof. Ernesto Leme, a convite do Prof. Braz Arruda, leu a mensagem que as professônes de Direito de 1932, enviaram aos combatentes do movimento constitucionalista, quando das comemorações de 11 de Agôsto, solidarizando-se e animando-os para a luta. Terminada a leitura, o Prof. Ernesto Leme ofereceu ao Centro Acadêmico XI de Agôsto um exemplar dessa mensagem que é a seguinte:

"Fazei chegar esta às mãos de um estudante da Faculdade de Direito de São Paulo". "Faculdade de Direito de São Paulo. - No dia em que se comemora a fundação dos cursos jurídicos, a Congregação da Faculdade de Direito de São Paulo envia comovidamente aos alunos de que tanto se orgulha, a sua saudação muito afetuosa e a afirmação de sua confiança inteira na vitória próxima da causa da lei e da libendade. São Paulo, 11 de Agôsto de 1932. - Alcantara 
Machado, Candida Motta, Cardoso de Mello Neto, João Arruda, Manuel Pedro Villaboim, Sampaio Doria, Reynaldo Porchat, Gama Cerqueira, Waldemar Ferreira, A. Almeida Junior, Honorio Monteiro, Jorge Americano"

Proferiu, a seguir, uma oração sôbre a data o Prof. Francisco Oscar Penteado Stevenson, que historiou o papel desempenhado pela Faculdade de Direito de São Paulo em todos os movimentos cívicos nacionais, desde a libertação dos escravos às campanhas de nossos dias. Recordou o orador episódios da Revolução Constitucionalista, rendendo, por fim, homenagens à memória de seus heróis. Foi dada, depois, a palavra ao estudante Odir Porto que, em nome do Centro Acadêmico XI de Agôsto, se associou às homenagens prestadas aos conbatentes de 1932. Após essa oração, dirigiram-se todos os presentes para as Arcadás da Faculdade, onde, junto ao monumento do Soldado Constitucionalista ali existente, guardado por Dragões da Independência, da Fôrça Pública, usou da palavra novamente o Prof. Braz Arruda. "Foi feito, por êste, o hasteamento da bandeira paulista. Referiu-se o mesmo à atuação dos voluntários da Faculdade no mowimento de 1932, fazendo a chamada simbólica de todos aquêles que haviam dado a sua vida para a glória de São Paulo e do Brasil. Finda essa cerimônia, o poeta Guilherme de Almeida declamou a poesia de sua autoria "Bandeira Paulista"

Convidou, depois; o presidente da mesa, todos os presentes a voltarem ao Salão Nobre, inde o Prof. Braz Arruda prestou uma homenagem ao Coronel Sampaio, que comandou o batalhão do qual faziam parte os alunos da Faculdade de Direito, recebendo, o mesmo, da assistência uma grande salva de palmas. O Coronel agradeceu, levantando um viva a São Paulo.

Em seguida, foi irradiada, pelo alto-falante instalado no recinto, a oração proferida pelo Prof. Alcantara Machado, diretor da Faculdade por ocasião da Revolução Constitucionalista, e dirigida aos combatentes que se achavam na linha de frente. Essa gravação pertence à Dra. Carlota Pereira de Queiroz. Foi também irradiada a gravação do Hino Acadêmico, por um côro de alunos. Por fim, de pé, a assistência ouviu o Hino Nacional executado pela banda da Fôrça Pública.

$$
\text { 12.a sessão - em 11 de Agôsto 'de 1949' }
$$

Foi, nessa data, realizada uma sessão solene da Congregação, no Salão Nobre da Faculdade; em comemoração da fundação dos eursos jurldicos no Brasil. Proferiu um discurso, alusivo à data, o acadêmico Mohamed Alli Silva Anção Sobrinho, primeiro orador do 
Centro Acadêmico XI de Agôsto. Em seguida, o Prof. Th. Monteiro de Barros Filho proferiu, em nome da Congregação, o discurso comemerativo da efemérida. Encerrando a sessão, o M. Reitor da Universidade, Prof. Miguel Reale, que presidiu a mesa, também salientou a significação do aniversário da fundação dos cursos jurídicos no Brasil.

\section{3. ${ }^{a}$ sessão — em 20 de Setembro de 1949}

F.oi feita a leitura de um ofício do Presidente do Centro Acadêmico XI ide Agôsto, comunicando que foi proposta e unânimemente aclamada uma moção de solidariedade e aprêço aos Professônes da Casa, especialmente aos Profs. Braz Arruda e Siqueira Ferreira. Além disto, a Assembléia do Centro Acadêmico resolveu solicitar à Congregação que considerasse encerrada a questão que motivou a suspensão dos alunos, admitindo-os aos exames com a turma de bacharelandos de 1949. Antes de ser discutido êste assunto, o Sr. Diretor da explicações sôbre a viagem que teve ocasião de fazer à Europa e da qual apresentará circunstanciado relatório.

Pediu, depois, a palavra, o Prof. Lino Leme, para apresentar as seguintes proposta:

I - "Tendo ocorrido a 15 de Agôsto último o centenário do nascimento de Amaro Cavalcanti; e, a 19 do mesmo mês, o de Joaquim Nabuco, proponho conste da ata a homenagem desta Faculdade a êsses inclitos vultos de nassa Pátria, que se converteram, por suas vidas e por seus trabalhos, em edificantes exemplos para os seus pósteros."

II - "Proponho se releve o restante da pena a que foram condenados, em princípio dêste ano, os estudantes José Antonio Pogé Ferreira e outros."

Pediu a palavra o Prof. Siqueira Ferreira, para agradecer à Congregação o voto de pesar consignado em ata pelo falecimento do Dr. Oscar Drummond Costa, agradecimento que fazia também em nome da familia Drummond Costa.

\section{4.a sessẫo - em 22 de Setembro de 1949}

o Prof. Lino Leme apresentou o seguinte substitutivo à proposta que, sôbre os estudantes suspensos, havia apresentado à na sessão anterior:

"Pronto que o apêlo do Centro Acadêmico XI de Agôsto seja encaminhado à comissão nomeada para tratar do assunto, a fim de que se digne encaminhá-lo ao Sr. Ministro da Educação, com parecer 
ressaltando que as penas aplicadas por esta Congregação já produziram os efeitos visados quanto à disciplina".

Passando-se à ordem do dia, o Prof. Noé Azevedo requereu a inversão da mesma, discutindo-se em primeiro lugar, o pedido dos bacharelandos, sôbre a colação de gráu, por se tratar de assunto urgente, devido às comemorações de centenário de Rui Barbosa.

Deferido êsse requerimento, a Congregação resolveu, por unanimidade, realizar a colação às 16 horas, no dia 5, no Salão Nobre da Faculdade.

Em seguida, a Congregação tomou várias deliberações:

1) Responder ao ofício do Diretor da Faculdade de Direito da Universidade do Rio Grande do Sul, informando que a Faculdade já organizou um ciclo de conferências sôbre Rui Barbosa, de modo que não pode atender às sugestões de Pôrto Alegre. A êste respeito, o Prof. Soares de Mello fez diversas considerações, declarando que possui o original da "Oração aos Moços", sugerindo que se publique esta, em fac-simile, para distribuição no dia 5 de Novembro. Esta proposta fớ aprovada unânimemente.

2) Remeter ao Conselho Técnico os pedidos de recondução dos livres docentes Vicente de Paulo Vicente de Azevedo, João de Deus Cardoso de Mello, Candido Motta Filho e' José Dalmo F. Belfort de Mattos.

3) Deferir o requerimento do Prof. Ataliba Nogueira sôbre a cadeira de Teoria Geral do Estado, remetendo-o ao Conselho Técnico para estudar a abertura do concurso da de Direito Constitucional.

\section{5. ${ }^{a}$ sessão - em 4 de Outubro de 1949}

O Prof. Noé Azevedo fez diversas considerações sôbre o Instituto de Direito Comparado, que funciona junto à Faculdade de Direito de Paris, da qual é Diretor o Prof. René David. Salientou que a criação de um Instituto de Direito Comparado em nossa Universidade, agregado à Faculdade de Direito, viria imprimir uma orientação científica a êsses estudos, despertando ainda major interêsse pelos mesmos, tornando-os, icertamente, mais produtivos. Para coordenar as iniciativas nacionais, em sua última reunião, realizada em Paris, sob a presidência do Dr. Torres Bodet, a UNESCO constituiu uma comissão internacional, compasta de onze membros, entre os quais figura o Prof. Tullio Ascarelli, catedrático de Direito Comercial em Bologna e professor contratado da nossa Faculdade durante algum tempo. Seria, pois, de grande vantagem que confiassemos a uma comissão de três professôres de que fizesse parte êsse eximio cultor do Direito, já tão ligado ao nosso estabelecimento universitário e ao nosso meio jurídico, a tarefa de elaborar o pro- 
jeto de nosso Instituto de Dineito Comparado e de promover a sua organização, de modo a possibilitar a çbra de cooperação previsista pela UNESCO. O Prof. Miguel Reale, atual Reitor da Universidade, está convencido de que é preciso adquirir um conhecimento aprofundado e claro das instituições juridicas dos diferentes povos, e não apenas dos preceitos e leis emanados dos Parlamentos e sujeitos às constantes mutações da política partidária ou dos regimes politicos Por isso, podemos contar com o seu, apoio junto ao Conselho Universitário e ao Govêrno do Estado, para que seja dotada a nossa Universidade, e particularmente a nossa Academia, dêsse Instituto, destinado a imprimir orientação científica às pesquisas nos vastos domínios do Direito Camparado. Assim, seria o Prof. Ascarelli contratado pela Universidade para participar dos trabalhos de organização do Instituto e para integrar a sua direção durante um certo prazo, com vencimentos correspondentes aos de professor catedrático da nossa Faculdade. Além dêsses trabalhos, regeria êle um curso especializado de Direito Comparado no Instituto de São Paulo e presidiria os trabalhos de seminário, que constituiriam a atividade fundamental do Instituto.

Aberta a discussão, pelo Prof. Ernesto Leme foi dito que a proposta dispensava outras considerações e que o Prof. Ascarelli, atualmente, era o mais notável dentre os comercialistas italianos. Votaria, assim, a favor da proposta. O Prof. Soares de Faria declarou que subscrevia a proposta do Prof. Noé Azevedo. Encerrados os debates, foi a proposta do Prof. Noé Azevedo submetida a votos e aprovada unânimemente.

Passando-se à ordem do dia, a Congregação tomou conhecimento da inscrição do Bacharel José Loureiro Junior no concurso à livre docência de Direito Constitucional, sendo ela aceita unànimeminte.

$$
\text { 16.a sessãa - em } 18 \text { de Outubro de } 1949
$$

o Prof. Érnesto Leme propôs fôssé consignado em ata un vuto de* profundo pesar pelo falecimento do Prof. Magalhães Drummond, oficiando-se à família do extinto e à Faculdade de Direito de Minas Gerais. A proposta foi aprovada unânimente.

A Congregação procedeu à eleição dos nomes a serem enviados à Reitoria e ao Govêrno do Estado, para o fim de ser escolhido o Vice-Diretor da Faculdade, nos termos da lei, pois o prazo da nomeação do Prof. Alvino Lima, que exercia o referido cargo, terminara em Setembro último. Procedida a eleição, verificou-se que os nomes mais votados foram os dos Prof. Lino de Moraes Leme, com 14 votos e Jorge Americano, icom 13 votos. Esses professôres agradeceram a indicação de seus nomes. 
A Congregação passou, em seguida, a deliberar sôbre diversas propostas do Conselho Técnico-Administrativo, sôbre Curso de Doutorado, cursos de extensão universitária, cursos de férias e contratos de professôres estrangeiros. O Prof. Noé Azevedo lembra que há uma comíssão, eleita pela Congnegação, para estudar o modo de funcionamento do Curso de Doutorado, parecendo-lhe que a atua? proposta deveria ser remetida à comissão, que sôbre ela se pronunciará. O Prof. Almeida Junior sugere que os demais assuntos sejam também remetidos à mesma comissão, lembrandó que ela estude a possibilidade da criação de bolsas para estudantes estran. geiros, que seriam indicados pelas respectivas Universidades, a fim de que façam aqui os cursos mencionados, pois, assim, os estudos se tornarão mais interessantes. Aceitas ambas as propostas, a Congregação resolveu remetê-las do Conselho Técnico à comissão, para estudos. O Prof. Basileu Garcia propõe, sendo unânimemente aprovado, que da comissão fique, também, fazendo parte, o Proí. Almeida Junior. A comissão ficou, pois, assim constituída: Profs. Braz Arruda, Jorge Americano, Siqueira Ferreira e Almeida Junior.

\section{7. a sessão - em 27 de Outubro de 1949}

o Prof. Soares de Mello comunica aos seus colegas que, na próxima $2 .^{a}$ feira, 31 de Outubro, às 20,30 horas, será inagurada, sor lenemente, na Biblioteca Municipal, a exposição comemorativa do centenário de Rui Barbosa, devendo falar o Prof. Ernesto Leme Desejava solicitar à Congregação, ou ao Sr. Diretor, autorização para retirar da Faculdade e entregar à comissão dos festejos comemorativos diversos documentos, como o "dossier", os livros de registro de diplomas e de matrícula, provas escritas, de Rui Barbosa, um quadro dêle, que se acha na Biblioteca, uma mesa com a assinatura de Rui e a coroa de louros, de ouro, que está guardada na tesouraria. Asssegurou o Praf. Soares de Mello que tudo seria devolvido à Faculdade, inclusive os demais documentos que serão expostos, documentos êsses que constituirão doação à Faculdade', após o encerramento da exposição. Pelo Sr. Diretor foi dito que a idéia só merecia louvores e aplausos e que providenciaria para a entrega à comissão dos documentos pedidos.

$$
\text { 18.a sessão - em } 21 \text { de Novembro de } 1949
$$

o Prof. Vicente Ráo declarou que desejava comunicar à Congregação ter o deputado Aureliano Leite lhe comunicado que fôra aprovado, em terceira discussão, o projeto de lei federal concedendo exames em segunda época a.os alunos que não tenham alcançado frequência. Disse ainda que o deputado Aureliano Leite, desde que 
obtivera conhecimento da deliberação da Congregação, de ver restabelecido o regime dos exames vagos em 2.a época, independentemente de frequência, se tornara defensor dêsse ponto de vista, na Câmara Federal, obtendo, em terceira discussão, a aprovação do projeto citado. Nessas condições, propunha que se consignasse em ata um voto de agradecimento ao Dr. Aureliano Leite, oficiando-se ao mesmo, nesse sentido. A proposta do Prof. Ráo foi aprovada sem discussão. O Prof. Siqueira Ferreira absteve-se de votar, por ser contrário ao projeto de lei.

\section{9. ${ }^{a}$ sessão - em 7 de Dezembro de 1949}

Esta sessão foi realizada na sala João Mendes Jr., em prosseguimento aos trabalhos do concurso à livre docência dé Direito Constitucional.

Aberta a sessão, o candidato proferiu a preleção sôbre o ponto sọrteado, que fôra o n. 7 : "Princípios constitucionais na organização judiciária do país”. Finda a preleção, os Srs. examinadores, Profs. Sampaio Doria, Vicente Ráo, Ernesto Leme, Soares de Faria e Th. Monteiro de Barros Filho procederam ao julgamento da prova, na forma da lei. Foi, então suspensa a sessão, para descanço, a qual se reabriu, quinze minutos depois, na mesma sala. Procedeu-se, em seguida, à abertura da urna, que continha a prova escrita feita pelo candidato, no dia 2 do corrente, sốbre o tema n. ${ }^{\circ} 10$ : - "Os partidos políticos e a Democracia. Situação do problema perante a Constituição Federal" O Bel. Loureiro Jr. leu sua prova escrita, sendo fiscalizado pelo Prof. Monteiro de Barros Filho. Terminada esta, os Srs. examinadores, procederam ao julgamento da prova, na forma legal.

A Comissão Examinadora apresentou o seu parecer, depois de terminadas tôdas as provas do concurso, aprovando o candidato por 3 votos contra dois. Submetido o parecer à Congregação, esta o rejeitou por 10 votos contra 3, não tendo votado os Srs. Membros da Comissão Examinadora.

\section{0.a sessão - em 15 de Dezembro de 1949}

Aberta a sessão, o Sr. Diretor comunica a aprovação da lei relativa aos exames de 2a. época, para os alunos sem frequência, pelo Senado Fiederal, lei cujo texto lê. Congratula-se com a Congregação por êsse fato, que solucionará a questão das faltas dos alunos.

Em seguida, o Sr. Diretor consulta a Congregação sôbre se esta quer reconsiderar a deliberação de só tomar conhecimento dos assuntos constantes da ordem do dia das sessões, cujos pareceres 
tenham sida copiados e distribuidos prèviamente aos Srs. Professôres, ou se quer modificá-la, permitindo a inclusão de novos assuntos. A Congregação manteve a deliberação anterior.

A respeito do concurso à livre docência de Direito Constitucional, em que foi candidato o Bacharel José Loureiro Junior, fizeram declarações os seguintes professôres: Vicente Ráo, Ernesto Leme, Miguel Reale, Almeida Junior e Monteiro de Barros Filho. Em seguida, foram lidos os pareceres sobre o julgamento do concurso, apresentados pelos professôres Lino de Morais Leme, José Soares de Mello e Joaquim Canuto Mendes de Almeida. O Prof. Vicente Ráo fez diversas considerações sôbre os aludidos pareceres, sendo acompanhado pelo Prof. Miguel Reale. O Prof. Almeida Junior leu uma justíficação do voto que apresentara anteriormente. Os Profs. Waldemar Ferreira, Ernesto Leme e Lino Leme fizeram declarações de voto.

Pediu a palavra o Prof. Soares de Mello e por êle foi dito que a Faculdade devia um agredecimento ao Magnífico Reitor, Prof. Miguel Reale, pela publicação em edição fac-similar da "Oração aus Moços". Não fôra a dedicaçạ̃ e o vivo interesse do Magnífico Reitor e a publicação não teria sido feita. E foi, segundo o depoimento de eminentes intelectuais do país, a mais notável publicação saida neste ano do centenário de Rui Barbosa, com referència ao mesmo. Propunha, pois, se consignasse em ata os agradecimentos da Faculdade ao Prof. Reale. A proposta do Prof. Soares de Mello foi aprovada unânimemente. O Prof. Siqueira Ferreira não votou, por ter-se retirada do recinto antes da votação. O Prof. Reale agradece a manifestação da Congregação, e declara que, como Reitor, apenas atendera financeiramente a proposta da Congregação, e que só a esta e à Faculdade pertencia a realização, para a qual contribuira com todo o trabalho o Prof. Soares de Mello.

\section{PRINCIPAIS DELIBERAÇס̃ES DO CONSELHO TECNICO ADMINISTRATIVO}

o Conselho Técnico-Administrativo da Faculdade de Direito de São Paulo realizou durante o ano de 1949 dezessete sessões. Entre suas deliberações, contam-se as seguintes:

1a. sessão - em 3 de Janeiro de 1949. - Nesta sessão, os senhores professôres membros do Conselho Técnico-Administrativo 
tomaram conhecimento das defesas, apresentadas por escrito, de quatro estudantes que fizeram diversas declarações pela imprensa.

2a. sessão - em 20 de Janeiro ởe 1949 - Entre outras resoluções, foram tomadas as seguintes: a) eleger os professôres A. de Sampaio Doria, Basileu Garcia e Almeida Junior para, em comissão, consolidar, em formas de regulamento, as disposições vigentes aplicáveis à Faculdade; b) fixar em dez, o número de vagas para estudantes estrangeiros ouvintes, sendo duas para cada ano. c) aprovar a seguinte proposta do Prof. Sampaio Doria: 1) iniciar os exames vestibulares em 16 de Fevereiro; 2) iniciar todos os exames de 2a. época em 16-2-49, abrindo-se a inscrição de 8 a 15 de Fevereiro; 3) realizar a aula inaugural do curso no dia $\mathbf{1}^{\circ}$. de Março, elegendo para proferir a prelação o. Prof. Basileu Garcia, ad refendum da Congregação; 4) uniciar as aulas a 2 de Março, ainda que incompleta a matricula, salvo obstáculo insuperável, a critério do Diretor; 5) aos aluinos que, por fôrça maior, deixaram de matríçular-se na época legal, só marcar faltas depois de efetuada a matrícula 6) não tendo sido apresentardo até 30 de Janeiro de cada ano os programas dêste ano, o Sr. Secretário mandará publicar os já apresentados em ano anterior, como atualizados, e os porá à venda, desdé o primeiro dia de aula; 7) declarar em ata do Conselho Técnico-Administrativo encerrados os exames de la. época, assim que terminem as chamadas respectivas; 8) lavrar Termo Geral de aprọação e promoção automática aos alunos com média de 7 para cima e frequência legal, sendo êsse termo assinado pelos professôres respectivos; 9) cọnsignar na segunda prova escrita dos alunos com média acima de 7 , e frequência legal, sua promoção automática, assinadas estas provas pelos respectivos professôres; 10) nomear uma comissão composta dos Profs. Sampaio Doria, Basileu Garcia e Almeida Junior para consolidar, em forma de regulamento, as disposições legais vigentes à Faculdade.

4a. sessão - em, 18 de Fevereiro de 1949 - O Conselho resolveu remeter à Congregação o processo n. ${ }^{0} 11.071$, da Reitoria da Universidade; sôbre o Prof. Ataliba Nogueira, indicando os nomes dosDrs. Florivaldo Linhares, Teodomiro Dias e Jorge da Veiga, para comporem a comissão que deverá dar parecer sôbre a transferência do Prof. Ataliba, ficando o $\mathrm{Sr}$. Diretor autorizado a indicar outros nomes, no caso de recusa dos ora indicados.

5a. sessão — em 22 de Fevereiro de 1949 - Passando à ordem do dia, o Conselho resolveu: - a) Realizar a aula inaugural no dia 21 de Março, estando a respectiva preleção a cargo do Prof. Sampaio Doria; b) considerando que a lei n.o 619, de 10-2-49 permite qué 
se inscrevam para exames de 2.a época os estudantes que excederam - limite de faltas por motivos ponderáveis, a juizo do Conselho Técnico-Administrativo; considerando que motivos ponderáveis foram auduzidos, oportunamente, pelos 'estudantes, não tendo sido acolhidos devido à severidade da legislação que na ocasião se aplicava; considerando que a verificação, de mạeira individual, dos motivos ponderáveis, șe reveste de dificuldades insuperáveis; o Conselho TécnicoAdministrativo resolve admitir a inscrição, para os exames de $\mathbf{2 a}$. época, todos os alunos que requererem.

6a. sessão - em 9 de Março de 1949 - O Conselho ficou ciente do ofício que o Prof. Cardoso de Mello Neto enviou, no qual requer sua exoneração do C. T. A., por ter assumido o cargo de deputado. federal, em caráter efetivo. $O$ Conselho resolveu consignar em ata as suas homenagens e úm voto de louvor ao Prof. Cardoso de Mello Neto, pelos bons serviços prestados' ao Conselho e à Faculdade. Nesta sessão, o Cónselho reśolveu que as matérias dé adaptação do curso dos alunos transferidos devem ser feitas' como dependências, sem aprovação nas quais não é possível promoção para o ano superior.

7a. sessão - em 24 de Março de 1949 - Passando-se à ordem do dia, foi decidido, quanto ao processo $n .^{\circ} 2613 / 49$, da Reitoria da. Universidade, sôbre a aluna Pilar Sanchez Catalán, o Conselho resolveu informar à Reitoria não dispör de verba para auxilio de viagem. e não permitir a lei a dispensa de frequência às aulas.

8a. sessão - em'1. ${ }^{\circ}$ de abril de 1949 - Nesta sessão, o Consetho aprovou o Regimento dos Auxiliares de Ensino.

9a. sessão - èm. 20 de Abril de 1949 - Resoluçâo tomada nesta sessão: indeferir a representação dó 'Presidente do Centro Acadêmico XI de Agôsto, sôbre abono de meio ponto, à vista do disposto no art. $2^{\circ}$., $\S 4^{\circ}$., da lei n.o 3 ; de 19-12-46.

10a. sessão - em 28 de Abril de 1949 - Aberta a sessão, o Conselho recebeu a visita do 'Prof. 'Zeferino' Vaz,' encarregado pela Universidade de estudar como deve ela participar da fundação dos cursos noturnos a que se refere o art. 23 da Constituição Estadual. o Prof. Zeferino Vaz expôs as vantagens e os inconvenientes e dificuldades' dos cursos noturnos. Tendo sido conovocada uma sessãa da Congregação, para as 15 horas de hoje, o Conselho, resolveu designar nova sessão para o dia 2 de Maio próximo, a fim de resolver o assunto, sessão à qual comparecerá o Prof. Zeferino Vaz. 
11a. sessão - em 2 de Maio de 1949 - A esta sessão compareceu o Prof. Zeferino Vaz, que continuou a exposição das vantagens e bem assim, desvantagens da criação dos cursos noturnos universitários. Finda a exposição, o Prof. Braz Arruda deu a sua opinião, tendo entregue, por escrito, ao Prof. Zeferino Vaz as suas razões, favoráveis aos cursos noturnos. Também se manifestaram de acôrdo com essa criação os Profs. Alvino Lima, Noé Azevedo e Basileu Garcia. Em resumo, o Conselho só vê vantagens na criação dos referidos cursos, a qual depende apenas de verba.

12a. sessão - em 13 de Mai॰ de 1940 - Passando-se à ordem do dia, foi lido um ofício do Prof. M. F. Pinto Pereira, que é o seguinte:

"Em data de 6 de Jullho de 1948, fui considerado estável como servidor público a partir de 10 de Julho de 1947, nos têrmos da apastila feita pelo Exmo. Sr. Governador do Estado no meu título de Professor contratado dessa Faculdade. Tendo, assim passado de livre-docente a Professor Estável, e com o único intuito dé bem servir, respeitosamente requeiro a V. Excia. haja por bem ouvir o douto Conselho Técnico e Administrativo dêsse Estabelecimento sôbre quais as atribuições que me competem, como decorrência de meu novo cargo".

O Conselho, em parecer, entendeu em conclusão, que se reconhecesse no Prof. Pinto Pereira direito a tomar parte nos trabalhos da Congregação, menos o de votar em matéria de concursos para - provimento de catedrático. Excluida esta função, nada obsta a que o Prof. Pinto Pereira participe dos demais trabalhos, como se catedrático fôsse.

Em seguida, o Consielho tomou conhecimento de diversos requerimentos de alunos da Faculdade. Resolveu, ainda, remeter à Congregação a proposta da Livraria Feitas Bastos sôbre prêmios para estudantes.

13." sessão - em 31 de Maio de 1949 - Aberta a sessão, fui empossado no cargo de membro do Conselho Técnico-Administrativo o Professor Waldemar Ferreira, nomeado por decreto 9 do corrente. O Conselho considerou a eleição do Prof. Waldemar Ferreira por um triênio, na vaga do Prof. Candozo de Mello Neto. Resolveu o Conselho levar ao conhecimento da Congregação a necessidade de apresentar dois nomes ao Gquêrno, para completar o têrço renovável do C.T.A. 
$\because \quad 14 .^{\mathrm{a}}$ sessão - em 30 de Setembro de 1949 - O Conselho tomó conhecimento de vários requerimentos de alunos.

Quanto à representação do C.A. XI de Agôstó, relativa à circular n. 3 da Divisão de Ensino Superior, entendeu o C.A.T. que não há 2. chamada. Entretanto, foi resolvido que o Sr. Diretor estaria autorizado a atender aos estudantes que, justificado o não comparecimento, por motivo de fôrça maior, dentro de quarenta e oito horas;; a contar da realização dos exames, o requeressem.

Relativamente aos pedido, 'de recondução dos livres docentes Vicente de Paulo Vicente de Azevedo, João de Deus Cardozo de Mello e José Dalmo F. Belfort de Mattos, o Conselho opinou pelo deferimento, entendendo o Prof. Sampaio Doria que os dois primeiros requerentes deveriam fazer a prova exigida pelo art. $46, \S 1 .^{\circ}$, da lei 3023 , e os demais conselheiros, que esta prova se deduz das próprias atividades dos requerentes. Resolveu o C.T.A. indeferir o requerimento de recondução do livre docente Candido Motta Filho na cadeira de Direito Penal, por já haver a respeito deliberação contrária da Congregação. O Prof. Braz Arruda não votou. O Prof. Noé Azevedo manteve o voto dado em Congregação.

Resolveu ainda opinar pelo deferimento do pedido constante da carta do Prof. Ataliba Nogueira, relativa à permanência dêste pròfessor na cadeira de Teoria Geral do Estado.

Em seguida, o Prof. Braz de Sousa Arruda aduziu diversas considerações sôbre um projeto de criação do cargo de professôres adjuntọ, aprovado pelo Conselho Universitário, e que, a seu requerimento, fốra remetido à comissão de ensino, para receber nova redação $\mathrm{em}$ diversos pontos. Acha razoável que o Conselho Técnico estude o assunto, relativamente à Faculdade de Direito, criando nesta, o cargo de assistente, para acesso ao qual seria indispensável a demonstração da capacidade do candidato, julgada esta, por exemplo, por uma comissão de professôres rresidida pelo catedrático da matéria. O Conselho resolveu aguardar a remessa de cópias do projeto, para deliberar sôbre o assunto.

15. ${ }^{\mathrm{a}}$ 'sessão — em 10 de Outubro de 1949 - Passando-se à ordem do dia, o Sr. Diretor fez diversas considerações sôbre a necessidade da reabertura do curso de Doutorado, da realização de cursos de extensão universitária, com professôres estrangeiros contratados, cursos equiparados práticos, curso de férias. Discutindo o assunto, o Conselho Técnico adotou as sugestões do Sr. Diretor, resolvendo: a) propor à Congregação a reabertura, quanto antes do curso 
de doutorado, atendendo ao grande interêsse existente por parte de avultado número de pessoas que aguardam as inscrições; b) propor à Congregação o contrato de professôres estrangeiros para realizarem cursos especializados nesta Faculdade, ouvido o Conselho Universitário, como é de lei. Lembram-se, desde já, os nomes dos professôres Jimenez de Asúa, Rafael Bielsa, Donnedieux de Vabres, René David e outros, cujos nomes possam ser sugeridos pela Congregação; c) instituir, na Faeuldade, cursos de extensão universitária, a serem realizados durante as férias, em épocas propicias á afluência de advogados, promotores públicas, juizes de direito nesta Capital. Esses cursos poderiam realizar-se em Julho, Dezembro e Janeiro, em conferências naturnas, ministradas por dois professôres em cada periodo de férias, de preferência de matérias diversas. Os programas seriam organizados com antecipação, dando-se publicidade.

Deliberou mais a Conselho conceder duas salas da Faculdade ao. Instituto de Direito Comparado.

16." sessão - em 4 de Novembro de 1949 - Passando-se à ordem do dia, o Conselho resolveu: a) conceder à aluna Leila Maria Junqueira de Mendonça o prêmio "Rodrigues Alves", por ser a estudante que melhores notas o;bleve na turma 1945-1949; b) conceder o prêmio "Theodureto de Carvalho Filhe", à aluna Maria Luiza de Castra Neves, por ter sido a melhor aluna do $40^{\circ}$ ano, em 1948.

17." sessão - em 21 de Dezembro de 1949 - Passando-se à ordem do dia, o Conselho resolveu: a) conceder vista ao Prof. Waldemar Ferreira dos requerimentos de $2 .^{\mathrm{a}}$ chamada de três alunos do $4 .^{\circ}$ ano, devido à informação nos mesmos dada pelo Prof. Jorge Americano; b) deferir o requerimento de recondução do livre docente Genésio de Almeida Moura, na cadeira de Direito, Público Constitucional, em virtude dos serviços prestados e por se achar na regência da cadeira; c) indeferir o requerimento da estudante Antonio Macedo ide Campos, pleiteando abono de faltas, por ter sido nomeado pelo Sr. Governador para integrar a comissão crganizadora dos Festejos Comemorativos do Centenário de Rui Barbosa. Esta deliberação foi tomada contra o voto do Prof. Noé Azevedo; d) indeferir o requerimento de um estudante, de abono de faltas por não ter apoio em lei. Em seguida, foi lido o oficio do Diretor da Faculdade de Direito da Pontificia Universidade Católica do Rio de Janeiro, relativa ao acadêmico. Herberto Marcondes Pereira, que, tendo 
prestado regularmente todos os atos escolares correspondentes à $5 .^{\text {a }}$ série na Faculdade Católica poderia ser conconsiderado apto a receber grau nesta Faculdade de Direito de $\mathbf{S}$. Paulo, visto ter sido impugnada pelo Ministério da Educação a transferência do referido acadêmico desta para aquela Faculdade', transferência que lhe foi concedida em 15-3-1949, de acordo com o art. 190 do Estatuto dos Funcionários Públicos da União. A Diretoria do Ensino Superior do Ministério da Educação também assim o entendeu, conforme telegrama n. 1594 , de 29-11-949, assim redigido: "Aluno Herberto Marcondes Pereira aprovado atos escolares, 5." série Faculdade Direito Pontifícia Universidade Católica Rio Janeiro, pode colar grau nessa Faculdade, desde que essa direção concorde. Ed. Superior". o Conselho resolveu não conceder a colaçãa de grau para não abrir precedente perigoso, que deve ser evitado. Os professôres Braz Arruda, Noé Azevedo e Alvino Lima votaram de acôrdo com o Prof. Waldemar Ferreira, que assim justificou a sua decisão: "Não pode, nem deve, a Faculdade de Direito da Universidade de São Paulc colar grau senão aos estudantes que nela concluem o seu curso. Está nesse caso o estudante Herberto Marcondes Pereira, que, ao que șe afirma, concluiu o seu curso na Faculdade de Direito da Universidade Católica do Rio de Janeiro. Transferido, a seu pedido, para aquela Faculdade, nela deve êle receber o seu grau. Não em outra. Se, por qualquer motivo, não pode comparecer pessoalmente para isso, no momento, que aguarde o mais oportuno, ou dê poderes para o compromisso de estilo. De resto, e isso é o mais importante, se tão esdrúxula pretensão for atendida, abrir-se-á precedente para manobras fraudulentas, que devem ser evitadas. Os maus precedentes são proliferos".

O Prof. Basileu Garcia declarou: "Bem ponderando acêrca da pretensão de que tratam os inclusos papéis, concluc, como os meus colegas do Conselho, que, tendo o estudante Herberto Marcondes Pereira realizado os seus exames do $5 .^{\circ}$ ano na Faculdade de Direito da Universidade Católica do Rio de Janeiro, não é possivel conceder-se-l he aqui nesta Faculdade a desejada colação de grau. Entretanto, penso que, como providência de equidade, conciliatória do "impasse", se lhe deve permitir que faça na proxima 2. épora, nesta Faculdade, os exames do $5 .^{\circ}$ ano, de maneira a poder aqui colar gráu. se for aprovado"

Em seguida, foi lido o requerimento em que o livre docente Genésio de Almeida Moura pleiteia lhe seja concedida a livre docência de Teoria Geral do Estado, como decorrência da sua aprovação 
ém concurso realizado em Setembro ide 1940 para a cadeira de Direito Público Constitucional, a qual, nesse mesmo mês, a 27, foi desdobrada em duas disciplinas, ou seja, nas de Direito Constitucional e Teoria Geral do Estado. Discutido o assunto, os Profs. Waldemar Ferreira, Alvino Lima e Basileu Garcia indeferiram o pedido por ter sido a cadeira criada depois do concurso para o: quad livire docente Genésio Moura foi nomeado. O Prof. Noé Azevedo declarou o seguinte: "Reconheço que o livre docente Genésio de Almeida Moura tem estudos especializados de Teoria Geral do Estado, suficientes para ser livre docente dä mesma. Basta ponderar que o mesmo está regendo esta cadeira. Mas a livre docência constitui título para conncurso de catedrático. Esse título deve ser obtido de acôrdo cołm tôdas as formalidades legais. Se em futuro concurso para catedrático, se apresentasse o Dr. Genésio com o título de livre docente de Teoria Geral do Estado e êste título influísse na sua classificação, poderia um concorrente impụgná-lo e obter mesmo a anulação do concurso". Foi, assim, indeferido o requerimento do livre docente Genésio de Almeida Moura, contra o voto do Prof. Braz Arruda, que a concedia.

\section{OUTRAS DELIBERAÇõES}

En 10 de Fevereiro - Reunião dos livres docentes da Faculdade dé Direito, para escolha do que deverá representá-los junto à Congregação dòs Professôres. Foi escolhido o Dr. Alfredo Buzaid.

Irm 14 de Março - O Sr. Diretor oficia ao Professor Miguel Reale, em seu nome e no da Congregação, cumprimentando-o pela sua eleição para membro titular do Instituto de Direito Comparado Latino e Americano da Universidade de Buenos Aires.

Em 10 de Setembro - E' publicada a Resolução $n^{\circ} 1 / 49$, do Magnífico Reitor da Universidade que, usando de suas atribuições e considerando a necessidade de melhor utilização da biblioteca «Silvio Portugal», resolve transferir para a Faculdade de Direito as obras de direito e as de referência, quando jurídicas.

\section{PREDIO DA FACULDADE}

Atenảendo a pedido da Diretoria desta Faculdade, o Magnifico Reitor da U:iversidade, Professor Miguel Reale, obteve, pelo decreto $n^{\circ} 18.890$, 
de 18-10-1949, a verba de $\mathrm{Cr} \$ 350.000,00$ (trezentos e cinquenta mil cruzeiros), destinada à conclusão do prédio desta Faculdade.

A Reitoria da Universidade de São Paulo procedeu à concorrência necessária para a execução das obras, tendo oferecido melhor preço a firma Salfatti \& Buchignani, que foi encarregada do serviço, o qual se acha pràticamente terminado.

\section{CONTRATOS DOS AUXILIARES DE ENSINO DA FACULDADE DE DIREITO}

\section{(Atos do Magnífico Reitor da Universidade)}

Bel. Alfredo Cecilio Lopes, cadeira de Economia Política.

Bel. Carmelita Gnecco de Camargo Braga, cadeira de Direito Internacional Público.

Eel. Egberto Lacerda Teixeira, cadeira de Direito Comercial.

Bel. Elcio Silva, cadeira de Legislação Social.

Bel. Fernando Rudge Leite, cadeira de Direito Civil.

Bel. Luiz Gonzaga B. M. Arrobas Martins, cadeira de Direito Internacional Privado.

Bel. Carlos Masagão, cadeira de Direito Administrativo.

Bel. Renato Cirell Czerna, cadeira de Introdução à Ciência do Direito.

Bel. Alaor de Lima, cadeira de Direito Civil.

Bel. Heladio de Toledo Monteiro, cadeira de Direito Comercial.

Bel. Teofilo Artur Siqueira Cavalcanti Filho, cadeira de Filosofia do Direito.

Bel. Milton França Moraes Leme, cadeira de Direito Civil.

Bel. Nelson Prezoto, cadeira de Direito Constitucional.

Dra. Est_ce. de Figueiredo Ferraz, cadeira de Direito Penal.

Dr. Flavio Queiroz de Moraes, cadeira de Direito Penal.

Dr. Joaquim Vieira Filho, cadeira de Medicina Legal.

Bel. Dimas de Oliveira Cesar, cadeira de Direito Civil.

Bel. Nilton Silva, cadeira de Direito Judiciário Penal.

Bel. Oscar Barreto Filho, cadeira de Direito Comercial.

Eel. Fabio Lopes Monteiro de Barros.

Dr. Gaetano Sciascia - por ato desta data, foi prorrogado seu contrato; por mais dois anos, junto à cadeira de Direito Romano.

Bel. Henrique Brito Vianna, cadeira de Teoria Geral do Estado.

Bel. Renato Cirell Czerna, que havia pedido exoneração do cargo de Auxiliar de Ensino da cadeira de Introdução à Ciência do Direito, é nomeado para outras funções, na Reitoria da Universidade.

Bel. Jorge Luiz de Moraes Dantas, cadeira de Introdução à Ciência do Direito. 


\section{PORTARIAS DO SNR. DIRETOR}

Portaria $n^{\circ}$ 1, de 4 de Janeiro - Comunicando que, em virtude da deliberação do Conselho Técnico-Administrativo da Faculdade, em sessão realizada a 3 de Janeiro, foram suspensos, a partir desta data, quatro estudantes desta Faculdade, um dêles por dois anos, outro por um ano e dois estudantes por trinta dias.

Portaria $n^{\circ}$ 2, de 10 de Janeiro - Exonerando, a pedido, D. Zilda Bottini, do cargo de servente diarista desta Faculdade.

Portaria $n^{\circ}$ 3, de 13 de Janeiro - Designando D. Ida Bottini para exercer as funções de servente diarista desta Faculdade.

Portaria n: 4, de 6 de Maio - Concedendo ao Prof. Antonio de Sampaio Doria sessenta dias de licença, para tratamento de saúde.

Portaria no 5, de 23 de Junho - Designando o servente diarista Sr. João Bottini para providenciar quanto à limpesa e asseio do edifício da Faculdade.

Portaria n 6, de 19 de Agosto - Concedendo ao Prof. Antonio de Sampaio Doria noventa dias de licença, para tratamento de saúde.

Portaria $n^{\circ} 7$, de $1^{\text {\% }}$ de Setembro - Designando o funcionário Joaquim de Oliveira para responder pelos serviços do Almoxarifado desta Faculdade; designando o servente Dirceu de Moura Baptista para servir na Tesouraria da Faculdade; designando o servente Claudic Leite para servir no Seminário de Legislação Social.

Portaria n ${ }^{\circ}$, de 15 de Setembro - Designando o Sr. Antonio Machado para exercer as funções de servente diarista desta Faculdade.

Portaria $n^{\circ}$ 9, de 26 de Setembro - Designando o Sr. Carmello Gangi para exercer as funçōes de servente diarista desta Faculdade.

Portaria $n^{\circ}$ 10, de 8 de Novembro - Elogiando os funcionários desta Faculdade, que concorreram, pela dedicação e esfôrço, para o maior brilho da solenidade de colação de grau dos bacharelandos de 1949. Agradece, especialmente, a colaboração do Sr. Secretário e do Sr. Tesoureiro.

Portaria $n^{\circ}$ 11, de $1^{\circ}$ de Dezembro - Designando D. Estela Ribeiro Barbosa para exercer as funções de servente diarista desta Faculdade.

Portaria $n^{\circ} \mathbf{1 2}$, de $1^{\circ}$ de Dezembro - Réconduzindo o Dr. José Dalmo Fairbanks Belfort de Mattos no cargo de livre docente de Direito Público Internacional.

Portaria n' 13, de 1' de Dezembro - Reconduzindo o Dr. João de Deus Cardozo de Mello no cargo de livre docente de Direito Judiciário Penal. 
Portaria $\mathrm{n}^{\circ}$ 14, de $1^{\circ}$ de Dezembro - Reconduzindo o Dr. Vicente de Paulo Vicente de Azevedo no cargo de livre docente de Direito Judiciário Penal.

Professor Spencer Vampré - Esteve afastado, durante o ano de 1949, para tratamento de saúde. Em 18 de Agôsto, decreto do Sr. Governador, concedendo um ano de licença, em prorrogação.

Professor Honório Monteiro - Esteve exercendo o cargo de Ministro do Trabalho.

Livre docente Candido Motta Filho - Designado para o cargo de Chefe do Gabinete do Ministro do Trabalho.

Professor S. Soares de Faria - Substituiu o Prof. Honório Monteiro na regência da cadeira de Direito Comercial, do $2^{\circ}$ ano.

Professor Miguel Reale - Substituiu o Prof. Spencer Vampré na regência da cadeira de Introdução à Ciência do Direito. Por decreto do' Sr. Governador, publicado a 7 de Agôsto, foi nomeado para exercer o cargo de Magnífico Reitor da Universidade de São Paulo.

Professor J. J. Cardozo de Mello Neto - Em exercício na Câmara Federal dos Deputados. Em 6 de Dezembro, foi publicado decreto do $\mathbf{S r}$. Governador, declarando competir ao Prof. Cardozo de Mello Neto mais a sexta parte de seus vencimentos.

Livre docente M. F. Pinto Pereira - Professor contratado para reger a cadeira de Direito Constitucional.

Professor Gabriel de Rezende Filho - De 24 de Janeiro a 15 de Fevereiro, em gôzo de férias regulamentares. Em 18 de Março solicitou demissão do cargo de Diretor da Faculdade. A partir de $1^{\circ}$ de Outubro, em gôzo de trinta dias de licença prêmio.

Professor Alvino Ferreira Lima - Substituiu o Prof. Gabriel de Rezende Filho na Diretoria da Faculdade. Em 18 de Março assumiu o exercício da Diretoria, até 21 de Junho. A partir de 17 de Julho, até 14 de Setembro, no exercício da da Diretoria, em substituição ao Prof. Braz Arruda, comissionado no estrangeiro.

Professor Antonio de Sampaio Doria - Licenciado, por motivo de saúde, a partir de 6 de Maio, por sessenta dias. Licenciado, por motivo de saúde, por noventa dias, a partir de $1^{\circ}$ de Agôsto.

Livre docente Luis Antonio da Gama e Silva - Substituiu o Prof. A. de Sampaio Doria, durante o tempo em que êste esteve licenciado, na regência da cadeira de Direito Internacional Privado.

Professor Noé Azevedo - A partir de 14 de Maio, afastado, por quarenta e cinco dias, a fim de representar a Faculdade na $6^{a}$ Conferência Interamericana de Advogados, a realizar-se em Detroit, U.S.A. 
Livre docente Flavio Queiroz de Moraes - Nomeado para substituir o Prof. Noé Azevedo na regência da cadeira de Direito Penal, do $2^{\circ}$ ano.

Professor Braz de Sousa Arruda - A partir de 17 de Julho foi concedido ao Prof. Braz de Sousa Arruda um afastamento de sessenta dias, a fim de percorrer diversos países da Europa, em viagem de intercâmbio universitário. A 14 de Setembro, de volta da Europa, reassume o exercício da Diretoria.

Livre docente J. Dalmo F. Belfort de Mattos - Substituiu o Prof. Braz Arruda na regência da cadeira de Direito Internacional Público, do $4^{\circ}$ ano.

Professor A. F. de Almeida Junior - A partir de 6 de Agôsto foi concedido a êste professor um afastamento, até 15 de Setembro, a fim de tomar parte no Seminário Interamericano de Alfabetização de Adultos, bem como na Reunião do Conselho Nacional de Educação, a serem realizados, respectivamente, em Petrópolis e no Rio de Janeiro. Por ato de 13 de Setembro, o afastamento foi prorrogado até 15 de Outubro.

Livre docente Hilário Veiga de Carvalho - Substituiu o Prof. Almeida Junior na regência da cadeira de Medicina Legal, do $4^{\circ}$ ano.

Professor Waldemar Martins Ferreira - A partir de $1^{\circ}$ de Agôsto, em gôzo de três meses de licença prêmio.

Livre docente Silvio Marcondes Machado - Substituiu o Prof. Waldemar Ferreira na regência da cadeira de Direito Comercial, do $4^{\circ}$ ano.

Professor Basileu Garcia - Em 22 de Agôsto, atọ do Magnífico Reitor da Universidade, concedendo a êste professor quarenta e sete dias de licença prêmio, restantes dos três meses que lhe haviam sidọ concedidos por ato de 18-9-48.

Livre docento Esther de Figueiredo Ferraz - A partir de 24 de Agôsto, substituiu o Prof. Basileu Garcia na regência da cadeira de Direito Penal, do $4^{\circ}$ ano.

Livre docente Luiz Eulalio de Bueno Vidigal - A partir de $1^{\circ}$ de Outubro, substituiu o Prof. Gabriel de Rezencle Filho, que obteve trinta dias ảe licença prêmio.

Professor Lino de Moraes Leme - Por decreto de 17 de Outubro foi nomeado Vice-Diretor da Faculdade. 


\section{COMEMORAÇõES E SOLENIDADES DURANTE O ANO DE 1949}

2 Ce Maio - Aula solene de abertura dos cursos da Faculdade, no Salão Nobre, estando a respectiva preleção a cargo do Prof. Antonio de Sampaio Dória, que discorreu sôbre o tema: Rui, homem de gênio e homem de bem.

4 de Julho - Sessão na Sala João Mendes, patrocinada pela Juventude Universitária Católica da Faculdade de Direito, sendo conferencista o Prof. Honório Monteiro, Ministro do Trabalho.

21 de Junho - Sessão na Sala João Mendes, patrocinada pelo Instituto dos Advogados, em homenagem ao $1^{\circ}$ aniversário da morte do Prof. Francisco Morato.

30 de Junho - Recepção da Congregação dos Professôres desta Faculdade, no Salão Nobre, ao Prof. Braz de Sousa Arruda, nomeado Diretor da Faculdade.

9 de Juho - Sessão soleze, no Salão Nobre, em comemoração ao aniversário da Revolução Constitucionalista de 1932.

11 de Agôsto - Comemoração solene da fundação dos Cursos Jurídicos no Brasil, estando a respectiva preleção a cargo do Prof. Theotônio Monteiro de Barros Filho.

5 de Setembro - No salão nobre da Faculdade, conferência do jurisconsulto inglês Lord Jowitt, patrocinada pela Reitoria da Universidade de São Paulo.

22 de Dezembro - Sessão solene, na Sala João Mendes, patrocinada pelo Seminário de Legislação Social, para, entrega de diplomas a alunos que concluiram o curso de Legislação Social.

20 de Outubro - Cerimônia da instalação do Iristituto Brasileiro de Filosofia e posse da Diretoria provisória. Conferência do Prof. Martial Gueroult, sôbre o cema: «Bergson en face des Philosophies». Conferências, na Sala João Mendes, às 9 e 10 horas, pelos alunos Dirceu Mello e Gelson Maldonado; temas: Rui, o Estudante e o Estudioso e Rui, o Imortal; patronos, Dr. A. Gontijo de Carvalho e Dr. Ubaldo Costa Leite.

21 de Outubro - Conferência do Prof. Joaquim Canuto Mendes de Almeida, às 21 horas, na Sala João Mendes, em comemoração ao centenário do nascimento de Rui Barbosa, sôbre o tema: Rui e o «habeas corpus.» Conferências na Sala João Mendes, em comemoração ao centenário de Rui Barbosa, às 7 e 10 horas, pelos alunos: Shajanan Flora e Ingeborg Sigrid Gerson; temas: Rui na intimidade 
e Rui o homem público; patronos, Prof. Soares de Mello e Dr. Julio de Mesquita Filho.

22 de Outubro - Conferências na sala João Mendes, às 9 e 10 horas, pelos alunos Francisco Bueno Torres e Marcio Fagundes, sôbre os temas: Rui e a história e Rui o Jurista e o Político; patronos, Prof. Flavio Queiroz de Moraes e Prof. Soares de Faria.

27 de Outubro - Conferências na sala João Mendes, às 9 e 10 horas, pelos alunos Yone Dolacio e Mucio Santos Vieira, sôbre os temas: Rui e o seu tempo e Rui e os estudantes; patronos, Des. Oswaldo Pinto do Amaral e Dr. Dolor de Brito Franco.

28 de Outubro - Conferências na Sala João Mendes, às 9 e 10 horas, pelos alunos Simão Burjakian e Oswaldo Barreto Filho; patronos, Dr. Abrahão Ribeiro e Des. Percival de Oliveira.

29 de Outubro - Conferências na Sala João Mendes, às 9 e 10 horas, pelos alunos Major Otaviano Costa e Antonio Pinto Martins, sôbre os temas: Rui e a liberdade e Rui e a campanha civilista; patronos, Dr. Correia Lima e Deputado Ulysses Guimarães.

3 de Novembro - Conferências na Sala João Mendes, às 9 e 10 horas, pelos alunos Alves Motta Sobrinho e Jayme Kawas, sôbre os temas: Rui literato e Rui e a abolição; patronos, Dr. Menotti del Picchia e Dr. Edgard França.

4 de Novembro - Conferências de encerramento da «Assembléia Rui Barbosa», organizadas pelos segundo-anistas da Faculdade de Direito, sob a orientação do Prof. M. F. Pinto Pereira: às 9 horas, Rui e as finanças, pelo Prof. Roberto Pinto de Souza; às 10 horas, Rui, apóstolo da dignidade humana, pelo Prof. Pinto Pereira.

5 de Novembro - Solenidade da colação de grau dos bacharelandos de 1949: às 10 horas, missa solene, oficiada pelo Cardeal arcebispo de São Paulo, D. Carlos Carmelo de Vasconcelos Motta; às 16 horas, colação de grau no Salão Nobre da Faculdade, tendo sido paraninfo o Prof. Miguel Reale, Magnífico Reitor da Universidade de São Paulo.

14 de Novembro - Aula solene de encerramento dos cursos, às 10 horas, no Salão Nobre, estando a respectiva preleção a cargo do Prof. José Soares de Mello, que discorreu sôbre o tema: Rui orador. 


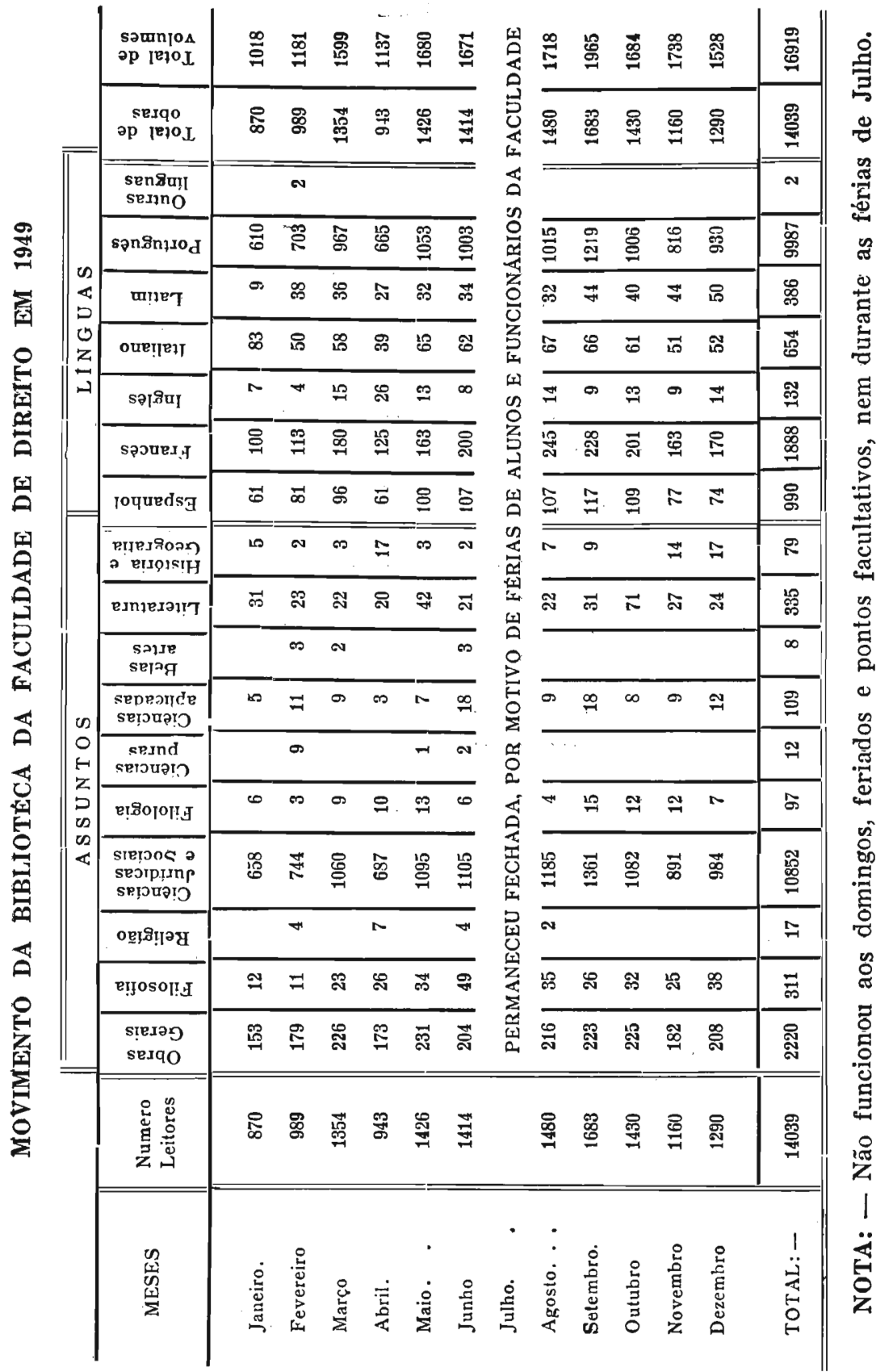




\section{RESULTADO DO CONCURSO DE HABIITACÃO EM 1949 \\ EXAME ONICO}

CANDIDATOS INSCRITOS

Sexo masculino

Sexo feminino $\ldots \ldots \ldots \ldots \ldots \ldots \ldots \ldots \ldots, 48$

$\ldots \ldots \ldots \ldots \ldots \ldots \ldots \ldots . .353$

\section{APROVADOS}

Sexo masculino

110

Sexo feminino

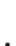

\section{F.E.B.}

João Ferreira de Albuquerque

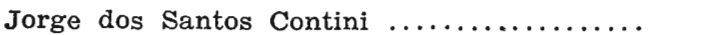

\section{REPROVADOS}

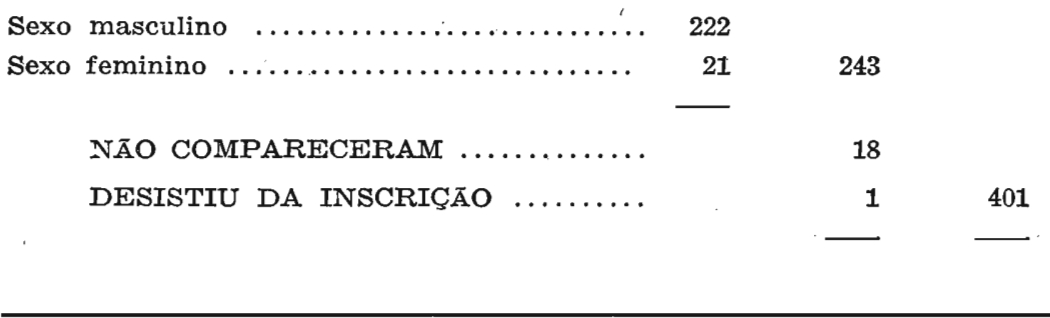

\section{PORCENTAGEM}

Aprovados Reprovados

Sexo masculino

334 (Excluindo-se 18 que não compareceram e 1 que desistiu da inscrição, 334 é o número dos que de fato prestaram exame) ........ $33,5 \%$ 66,5\%

Sexo feminino 


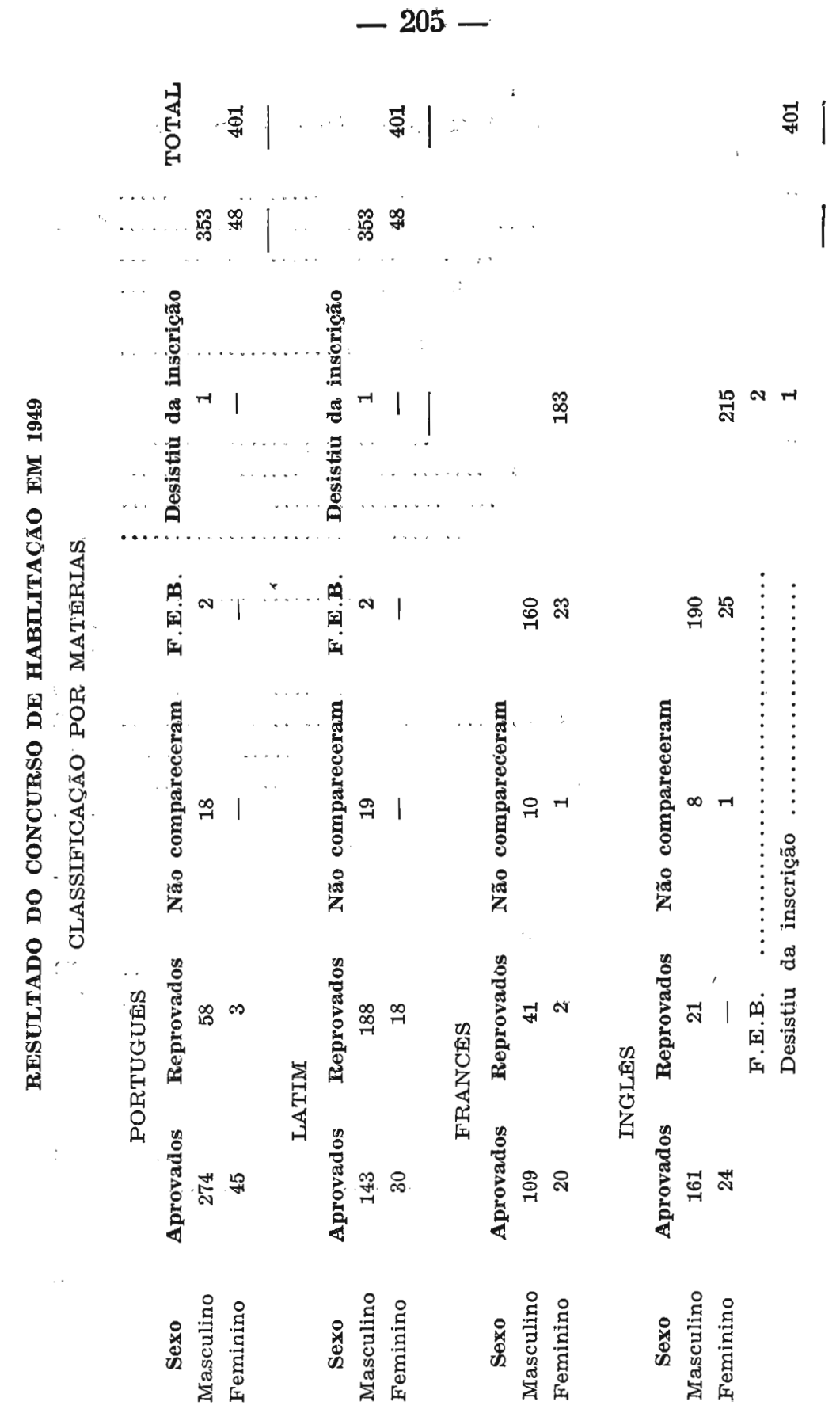




\section{RELAÇÃO DOS ALUNOS MATRICULADOS EM 1948}

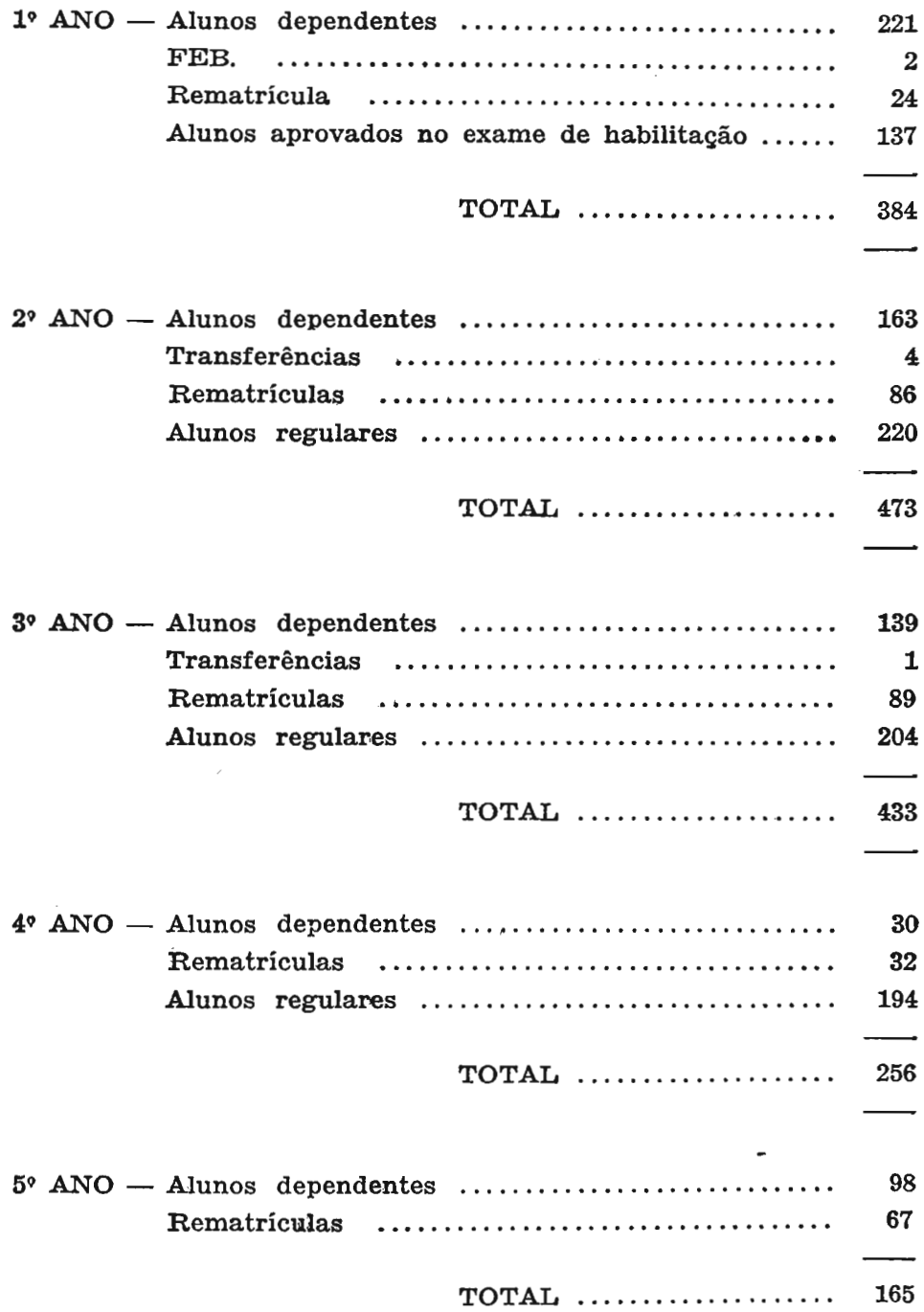

